\title{
Combination of gold catalysis and Selectfluor for the synthesis of fluorinated nitrogen heterocycles
}

\author{
Antoine Simonneau, Pierre Garcia, Jean-Philippe Goddard, \\ Virginie Mouriès-Mansuy, Max Malacria* and Louis Fensterbank ${ }^{*}$
}

\section{Full Research Paper}

Open Access

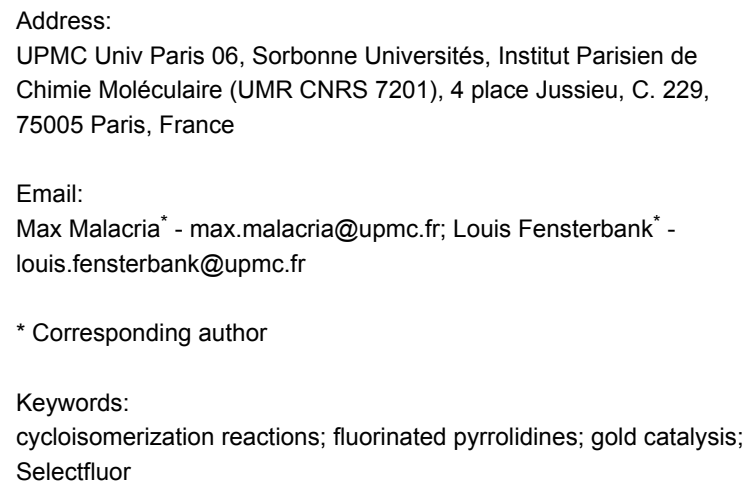

\begin{abstract}
We herein report the synthesis of 3-fluoro-2-methylene-pyrrolidine (3a) and -piperidine (3b) from 1,5- and 1,6-aminoalkynes, respectively, using a combination of a gold-catalyzed hydroamination reaction followed by electrophilic trapping of an intermediate cyclic enamine by Selectfluor. Careful attention was paid to the elucidation of the mechanism and Selectfluor was suggested to play the double role of promoting the oxidation of gold(I) to a gold(III) active species and also the electrophilic fluorination of the enamine intermediates.
\end{abstract}

\section{Introduction}

The useful properties of fluorinated compounds in medicinal chemistry have motivated an intense effort towards the synthesis of new molecules bearing fluorine substituents [1,2]. Therefore, the development of a rapid access to C-F bonds is of great importance. Quite recently, in their study on the synthesis $\alpha$-fluoro ketones, Nevado et al. observed the formation of fluorinated pyrrolidinol obtained by a gold-catalyzed cyclization of a 1,5-aminoalkyne in the presence of Selectfluor (Scheme 1) [3]. These authors proposed that the formation of the $\mathrm{C}\left(\mathrm{sp}^{3}\right)-\mathrm{F}$ bond could be explained either by direct fluorina- tion of the enamine resulting from the gold-promoted alkyne hydroamination or by oxidation of the intermediate vinyl gold(I) complex by Selectfluor into a gold(III) fluoride species followed by a reductive elimination.

Moreover, the formation of $\mathrm{C}\left(\mathrm{sp}^{2}\right)-\mathrm{F}$ bonds, either by hydrofluorination of alkynes catalyzed by $\mathrm{N}$-heterocyclic carbene gold(I) complexes [4], or by fluorodeauration of transient vinyl gold species $[5,6]$, has been previously reported in the literature. 


$$
\begin{aligned}
& \text { } \\
& 80^{\circ} \mathrm{C}, 1.5 \mathrm{~h}
\end{aligned}
$$

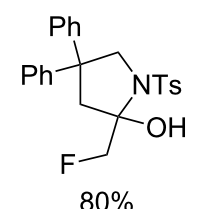

$80 \%$
Scheme 1: Amino-hydroxyfluorination of alkynes reported by Nevado et al. [2].

On the basis of our recent results on the gold-catalyzed cyclization of enynes [7-10] and allenylhydrazones [11], as well as the studies from Nevado [3], Hammond and Xu [12], Liu and Xu [13], and Liu [14], we were attracted by the possibility to access fluorinated nitrogen heterocycles $\mathbf{2 a}$ and $\mathbf{2 b}$ by performing subsequently an intramolecular nucleophilic attack of nitrogen onto the gold-activated triple bond on compounds $\mathbf{1 a}, \mathbf{b}$ in a 5and 6-exo-dig manner, respectively, and reductive elimination occurring at a vinyl gold(III) fluoride species or bimolecular fluorodeauration (Scheme 2). We also anticipated from this study to gain more insight into the reactivity of gold catalysts/ Selectfluor combinations [15-17].

Indeed, pyrrolidine and piperidine skeletons are very attractive ring systems because of their occurrence in numerous biologically active substances, and the design of methodologies allowing the easy introduction of a fluorine atom onto these skeletons could be attractive for medicinal chemists. Recently

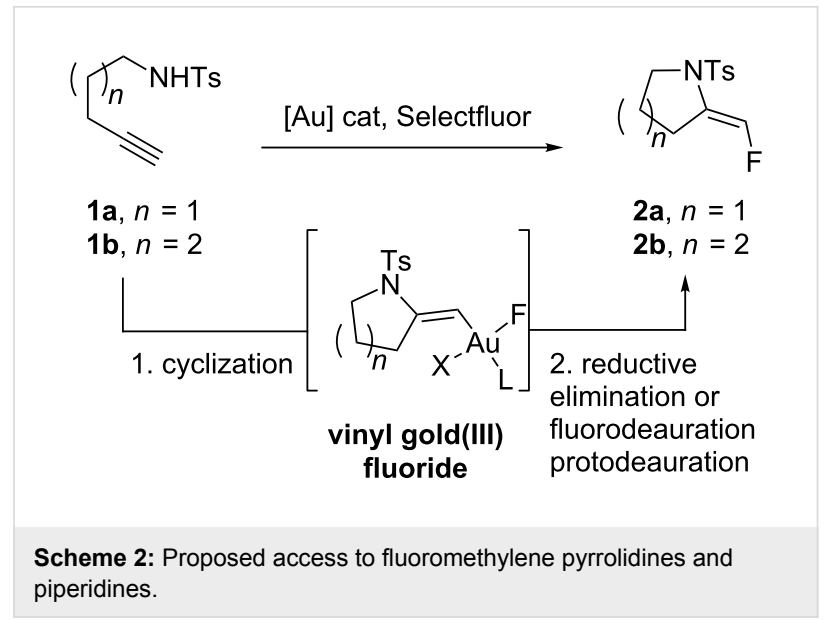

also, the literature has featured valuable access routes to pyrrolidine promoted by catalytic systems [18-26].

\section{Results and Discussion}

Studies on the scope and limitation of the cyclization-fluorination sequence were carried out with Selectfluor as a source of electrophilic fluorine. Readily available 4-methyl- $\mathrm{N}$-(pent-4ynyl)benzenesulfonamide (1a) was used as a model substrate, and all the reactions were performed in anhydrous acetonitrile as the solvent. Various gold catalysts were screened. The results of the optimization of the cyclization reaction conditions are summarized in Table 1.

Table 1: Gold catalyst influence on the cyclization of $1 a^{a}$<smiles>C#CCCCNC(F)(F)F</smiles>

$1 \mathbf{a}$

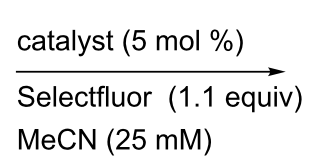

$\mathrm{rt}, 12 \mathrm{~h}$<smiles>C=C1C(F)CC[NH+]1[S-]</smiles>

$3 a$<smiles>FCC1=CCC[NH+]1[Sn]</smiles>

\begin{tabular}{|c|c|c|c|c|}
\hline Entry & Catalyst & 3a (yield \%) & 4a (yield \%) & $5 a($ yield \%) \\
\hline $1^{b}$ & $\mathrm{Ph}_{3} \mathrm{PAuCl}$ & 75 & 17 & 0 \\
\hline $2^{\mathrm{C}}$ & $\mathrm{AuCl}$ & 46 & 0 & 7 \\
\hline $3^{b}$ & $\mathrm{AuCl}_{3}$ & 14 & 2 & 2 \\
\hline 4 & IPrAuCl & 65 & 13 & 0 \\
\hline $5^{d}$ & $($ biphenyl $)(t-\mathrm{Bu})_{2} \mathrm{PAuCl}$ & 0 & 0 & 0 \\
\hline 6 & $(\mathrm{PhO})_{3} \mathrm{PAuCl}$ & 35 & 7 & 0 \\
\hline 7 & $(2,4-\mathrm{di}-t-\mathrm{BuPhO})_{3} \mathrm{PAuCl}$ & 35 & 5 & 0 \\
\hline 8 & $(t-\mathrm{Bu})_{3} \mathrm{PAuCl}$ & 35 & 6 & 0 \\
\hline 9 & $\operatorname{dppm}(\mathrm{AuCl})_{2}$ & 43 & 0 & 14 \\
\hline 10 & $\mathrm{Ph}_{3} \mathrm{PAuNTf}{ }_{2}$ & 35 & 0 & 11 \\
\hline 11 & {$\left[\mathrm{Ph}_{3} \mathrm{PAu}\right] \mathrm{SbF}_{6}$} & - & - & - \\
\hline
\end{tabular}

$5 \mathbf{a}$

aproducts $3 \mathbf{3 a}, \mathbf{4 a}$ and $\mathbf{5 a}$ were characterized by ${ }^{1} \mathrm{H},{ }^{13} \mathrm{C}$ and ${ }^{19} \mathrm{~F}$ NMR. Compound $\mathbf{4 a}$ was obtained as a single $(E)$-isomer and the configuration of the double bond was confirmed by NOE measurements. ${ }^{b}$ When the reaction was performed without Selectfluor, the starting material was recovered unchanged. ${ }^{\mathrm{C}}$ Reaction time: $5 \mathrm{~h}$. ${ }^{\mathrm{d}} \mathrm{An}$ inextricable mixture was obtained. 
The reaction of $\mathbf{1 a}$ in the presence of commercially available $\mathrm{Ph}_{3} \mathrm{PAuCl}$ (5 mol \%) and Selectfluor (1.1 equiv) in acetonitrile at $\mathrm{rt}$ afforded an inseparable mixture of pyrrolidines $\mathbf{3 a}$ in $75 \%$ yield and 4a in $17 \%$ yield (Table 1, entry 1). Difluoro derivative 4a was isolated as a single diastereomer, and its relative stereochemistry was determined by F-F NOE measurement The expected fluoromethylene tosylpyrrolidine 2a was not detected. When a $\mathrm{AuCl}$ complex was used, product 3a was obtained in $46 \%$ yield with a new monofluorinated 2-pyrroline 5a in $7 \%$ yield (Table 1, entry 2). In the presence of $\mathrm{AuCl}_{3}$, a lower yield of $\mathbf{3 a}$ was observed (14\%) with trace amounts of $\mathbf{4 a}$ and $5 \mathbf{a}$ ( $2 \%$ yield each, Table 1 , entry 3$)$. The use of the $N, N$ bis(2,6-diisopropylphenyl)imidazol-2-ylidene (IPr) gold(I) chloride as catalyst led to the formation of $\mathbf{3 a}$ in $65 \%$ yield, together with $13 \%$ yield of $\mathbf{4 a}$. Under these conditions, the formation of 5a was not detected (Table 1, entry 4). Gold(I) phosphite catalysts gave 3a and $\mathbf{4 a}$ in low yields (Table 1, entries 6 and 7). A similar result was observed with tri(tertbutyl)phosphine gold(I) chloride (Table 1, entry 8). The dinuclear complex, $\operatorname{dppm}(\mathrm{AuCl})_{2}$, led to $\mathbf{3 a}$ and $\mathbf{5 a}$ in a manner comparable to $\mathrm{AuCl}$ (Table 1, entry 9). When we used cationic gold(I) catalyst, $\mathrm{Ph}_{3} \mathrm{PAuNTf}_{2}$, 3a was obtained in $35 \%$ yield with $11 \%$ of $5 \mathbf{a}$ (Table 1, entry 10). Finally in the presence of $\left[\mathrm{Ph}_{3} \mathrm{PAu}\right] \mathrm{SbF}_{6}$ a complex mixture of compounds was obtained (Table 1, entry 11). To the best of our knowledge, these fluorinated pyrrolidines 3a, 4a and 2-pyrroline 5a are unknown and could be interesting building blocks for organic synthesis.

Following the previous catalyst screening, we stuck with the use of $\mathrm{PPh}_{3} \mathrm{AuCl}$ as the catalyst and next investigated the effect of the concentration of 1a and the stoichiometry of Selectfluor (Table 2).
Reaction of a $75 \mathrm{mM}$ solution of 1 a with $\mathrm{Ph}_{3} \mathrm{PAuCl}$ (5 mol \%) and Selectfluor (1.5 equiv) in acetonitrile under reflux (Table 2, entry 1) afforded an inseparable mixture of $\mathbf{3 a}$ and $\mathbf{4 a}$ both in $25 \%$ yield. When the reaction was performed at room temperature, 3a could be isolated in $47 \%$ yield with $17 \%$ of $4 \mathbf{a}$ (Table 2, entry 2). Using lower amounts of Selectfluor raised the yield of $\mathbf{3 a}$ to $54 \%$ and $\mathbf{4 a}$ to $13 \%$ (Table 2, entry 3). In the presence of two equivalents of potassium carbonate the cyclization reaction did not occur (Table 2, entry 4). Lowering the temperature to $5^{\circ} \mathrm{C}$ led to a dramatic decrease of the yield of 3a and 4a (Table 2, entry 5). Interestingly, the yield of $\mathbf{3 a}$ increased up to $75 \%$ when a lower substrate concentration was used ( $25 \mathrm{mM}$, Table 2, entry 6). Going to an even more dilute medium resulted in the sole formation of $\mathbf{3 a}$ (Table 2, entry 7). It is noteworthy that in the absence of either the gold catalyst or Selectfluor, the starting material was recovered.

The homologue of $\mathbf{1 a}$, compound $\mathbf{1 b}$, was treated with $\mathrm{Ph}_{3} \mathrm{PAuCl}(5 \mathrm{~mol} \%)$ and Selectfluor (1.1 equiv) in acetonitrile at rt. As expected, the 6-exo-dig cyclization occurred and only led to one compound, $\mathbf{3 b}$, which was isolated in $43 \%$ yield (Scheme 3).

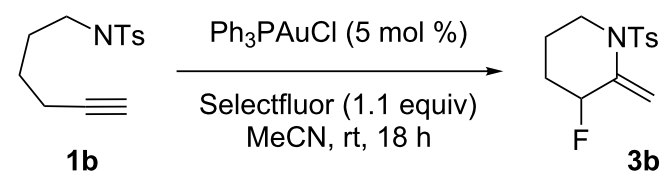

$43 \%$

Table 2: Effects of reaction conditions on the $\mathrm{Au}(\mathrm{I})$-catalyzed cyclization of 1a in the presence of Selectfluor.

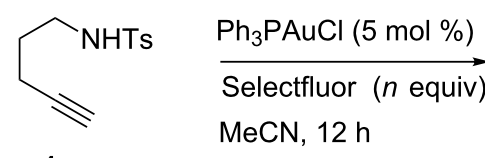

$1 \mathbf{a}$<smiles>C=C1C(F)CC[N+]1(C)S</smiles>

$3 a$

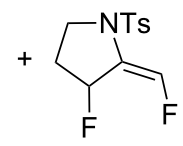

$4 a$

\begin{tabular}{|c|c|c|c|c|c|}
\hline Entry & $n$ (equiv) & Substrate concentration (mM) & Temperature & 3a (yield \%) & $\mathbf{4 a}$ (yield \%) \\
\hline $1^{a}$ & 1.5 & 75 & reflux & 25 & 25 \\
\hline 2 & 1.5 & 75 & $\mathrm{rt}$ & 47 & 17 \\
\hline 3 & 1.1 & 75 & $\mathrm{rt}$ & 54 & 13 \\
\hline $4^{b}$ & 1.1 & 75 & $\mathrm{rt}$ & 0 & 0 \\
\hline 5 & 1.1 & 75 & $5^{\circ} \mathrm{C}$ & 17 & 2 \\
\hline 6 & 1.1 & 25 & $\mathrm{rt}$ & 75 & 17 \\
\hline 7 & 1.1 & 15 & $\mathrm{rt}$ & 73 & 0 \\
\hline
\end{tabular}

aReaction time: $1 \mathrm{~h}$. b2 equiv of $\mathrm{K}_{2} \mathrm{CO}_{3}$ were added. 
Our mechanistic proposal for the formation of fluorinated pyrrolidines is outlined in Scheme 4. Oxidation of the $\mathrm{Au}(\mathrm{I})$ complex by Selectfluor should give the active cationic $\mathrm{Au}(\mathrm{III})$ species A. Formation of $\mathbf{A}$ is consistent with ${ }^{19}$ F NMR experiments analogous to those previously described in the literature $[12,27]$. Thus, upon addition of Selectfluor to $\mathrm{PPh}_{3} \mathrm{AuCl}$, a new peak at $-181.6 \mathrm{ppm}$ in $\mathrm{CD}_{3} \mathrm{CN}$ was observed that is characteristic of $\mathrm{Au}$ (III) species $\mathbf{A}$ [28]. Coordination of $\mathbf{1 a}$ to $\mathbf{A}$ would lead to complex $\mathbf{B}$ in which the coordinated triple bond is activated towards a nucleophilic attack by the NH moiety. The resulting $\sigma$-vinyl $\mathrm{Au}(\mathrm{III})$ intermediate $\mathbf{C}$ could undergo a reductive elimination of its $\sigma$-vinyl and $\mathrm{F}$ ligands to give $\mathbf{2 a}$, or a protodeauration leading to pyrrolidine $\mathbf{6}$, which would also rapidly isomerize into 7 . Both 6 and 7 under the given reaction conditions would evolve to $\mathbf{3 a}$ and $\mathbf{5 a}$.

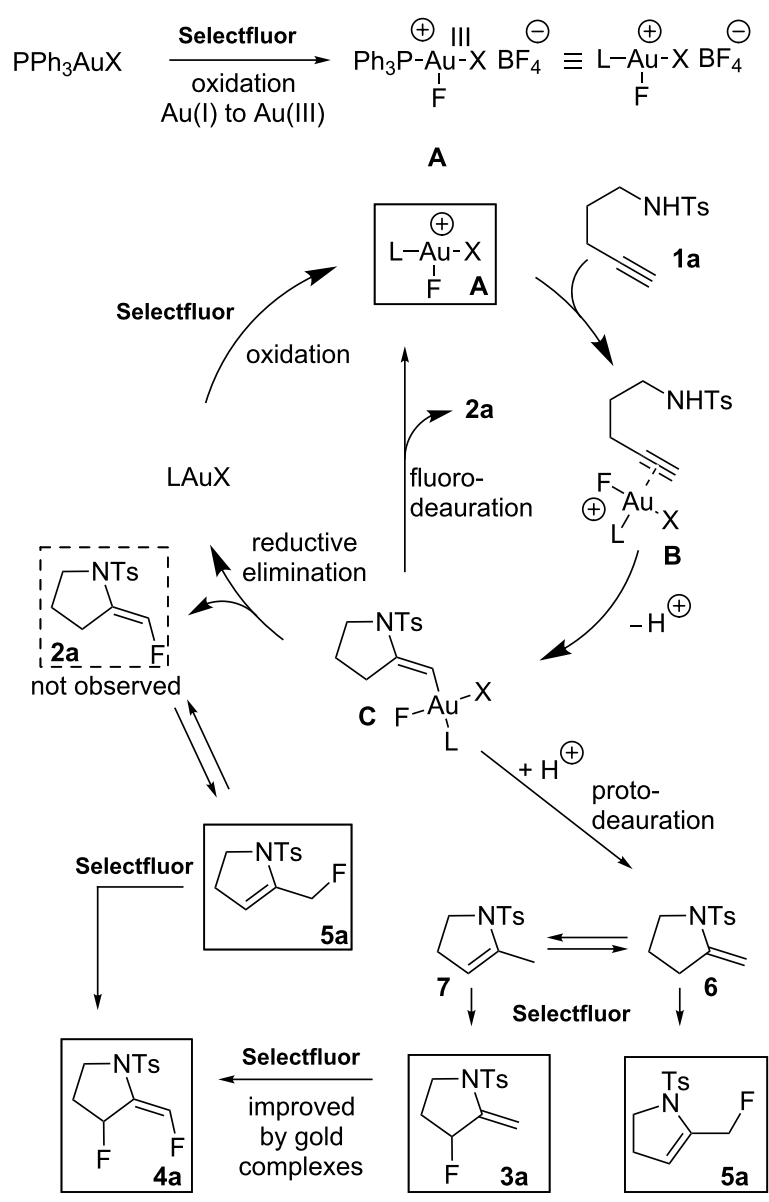

Scheme 4: Proposed mechanism.

The following experiments were performed to probe the mechanism proposed in Scheme 4. The reaction of a mixture of 6 and 7, in a 2:3 ratio, with $\mathrm{PPh}_{3} \mathrm{AuCl}(5 \mathrm{~mol} \%)$ and Selectfluor
( 1 equiv) in acetonitrile at $\mathrm{rt}$ during $3 \mathrm{~h}$, led to a mixture of $\mathbf{3 a}$ and $5 \mathbf{a}$ with yields of $74 \%$ and $4 \%$, respectively. In the absence of a gold catalyst, a similar result was obtained (Scheme 5) confirming that Selectfluor itself can react with $\mathbf{6}$ and $\mathbf{7}$ to give 3a and 5a, which is consistent with Shreeve's study on the fluorination of enamines [29].

However, the formation of $\mathbf{5 a}$ may also be ascribed to the reductive elimination of $\mathbf{C}$, which leads to $\mathbf{2 a}$, and then further isomerization of the double bond of $\mathbf{2 a}$ (Scheme 4). As far as the formation of $\mathbf{4 a}$ is concerned, we found that treatment of 3a with one equivalent of Selectfluor in the presence of $\mathrm{Ph}_{3} \mathrm{PAuCl}$ (5 mol \%), led to $4 \mathbf{a}$ in $81 \%$ yield. Nevertheless, in the absence of $\mathrm{Au}(\mathrm{I})$ catalyst, $4 \mathrm{a}$ was also formed but with a lower yield of $38 \%$ (Scheme 5). These results suggest that the formation of $4 \mathbf{a}$ may not exclusively result from the Selectfluor-mediated fluorination of 3a. These findings are consistent with Gouverneur's study [5], which showed a competition between fluorodeauration and protodeauration. In our case, protodeauration appears to be the major, if not the exclusive, pathway.
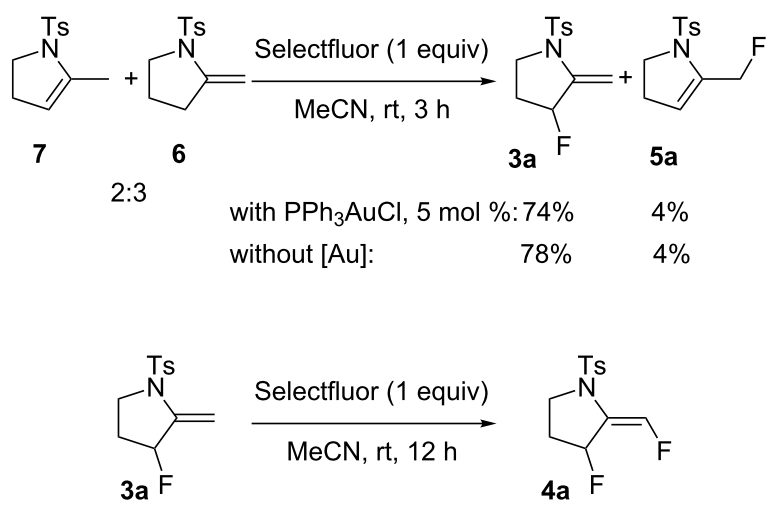

with $\mathrm{PPh}_{3} \mathrm{AuCl}, 5 \mathrm{~mol} \%$ : $\quad 81 \%$ without $[\mathrm{Au}]: \quad 38 \%$

Scheme 5: Mechanistic probes.

In a final experiment, 1 a was treated with $\mathrm{PPh}_{3} \mathrm{AuNTf}_{2}$, without Selectfluor, and dimer 8 was formed in $63 \%$ yield along with 6 and 7 in low yields of $2 \%$ and $8 \%$, respectively. The formation of 8 could be explained as outlined in Scheme 6 . The cationic $\mathrm{Au}(\mathrm{I})$ catalyst would promote the cyclization of $\mathbf{1 a}$ to the mixture of enamines $\mathbf{6}$ and $\mathbf{7}$ as previously observed with cationic $\mathrm{Au}(\mathrm{III})$ species (Scheme 4). Activation of the electron rich double bond of $\mathbf{6}$ or 7 by the cationic Au(I) complex could finally trigger the dimerization and so the formation of 8 . 


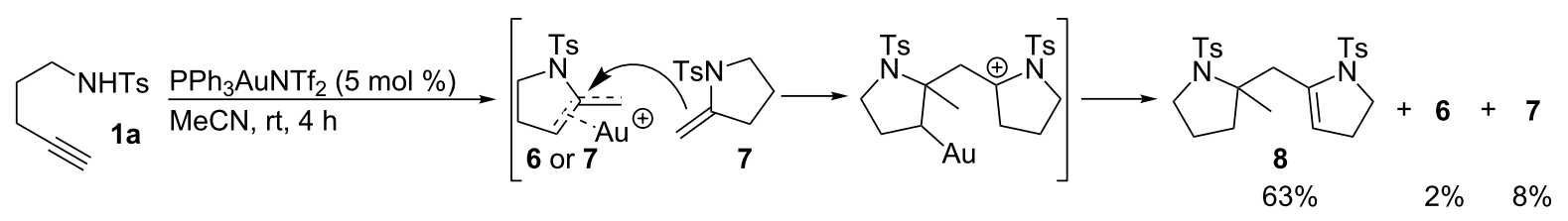

Scheme 6: Cationic $A u(I)-c a t a l y z e d$ reaction of 1a without Selectfluor.

\section{Conclusion}

In conclusion, we have reported a gold-catalyzed synthesis of fluorinated pyrrolidines from 1, $\omega$-aminoalkynes using Selectfluor as the source of fluorine. This method allows a rapid, efficient and mild conversion of readily available aminoalkynes into valuable nitrogen heterocycles substituted by a fluorine atom in position 3 of the ring. This could certainly be applied to the synthesis of biologically relevant substrates. Current efforts are being made in this direction and a more exemplified study will be reported in due course.

\section{Experimental}

\section{General methods}

Acetonitrile was distilled over calcium hydride. Other reagents were commercially available and used without further purification. Thin layer chromatography (TLC) was performed on Merck $60 \mathrm{~F}_{254}$ silica gel. Acros aluminium oxide, basic, Brockmann I, 50-200 $\mu \mathrm{m}, 60 \mathrm{~A}$ was used for column chromatography. NMR spectra $\left({ }^{1} \mathrm{H},{ }^{13} \mathrm{C}, \mathrm{DEPT}, \mathrm{COSY}, \mathrm{HMQC}, \mathrm{HMBC}, \mathrm{NOE}\right)$ were recorded at room temperature at 300 or $400 \mathrm{MHz}$ on a Bruker AVANCE spectrometer. Chemical shifts are given in ppm, referenced to the residual proton resonance of the solvents $\left(\delta=7.26\right.$ for $\left.\mathrm{CHCl}_{3}\right)$ or to the residual carbon resonance of the solvent $\left(\delta=77.16\right.$ for $\left.\mathrm{CDCl}_{3}\right)$. Coupling constants $(J)$ are given in Hertz $(\mathrm{Hz})$. The terms $\mathrm{m}, \mathrm{s}, \mathrm{d}, \mathrm{t}$ and q refer to multiplet, singlet, doublet, triplet and quartet; br means that the signal is broad. When possible, ${ }^{1} \mathrm{H}$ and ${ }^{13} \mathrm{C}$ signals were assigned on the basis of DEPT and 2D NMR (COSY, HMBC) experiments. Low-resolution mass spectra (MS) and high-resolution mass spectra (HRMS) were measured on a Bruker MicroTOF mass spectrometer. Infrared spectra (IR) were recorded on a Bruker Tensor 27 spectrometer and melting points were measured on a Wagner \& Munz HEIZBANK Kofler bench.

\section{General procedure for the synthesis of precursors}

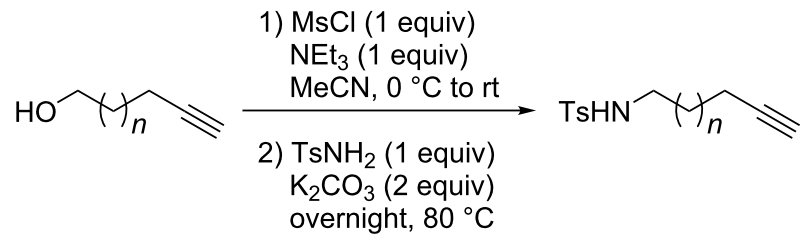

To a cold solution $\left(0^{\circ} \mathrm{C}\right)$ of the starting alcohol in $\mathrm{MeCN}, \mathrm{MsCl}$ and $\mathrm{Et}_{3} \mathrm{~N}$ were successively added, and the mixture was warmed to rt. After $1 \mathrm{~h}, \mathrm{~K}_{2} \mathrm{CO}_{3}$ and $\mathrm{TsNH}_{2}$ were added and the mixture was warmed at $80{ }^{\circ} \mathrm{C}$ overnight. Once back to rt, the mixture was directly purified by flash chromatography being eluted first with petroleum ether and then with petroleum ether/ ethyl acetate 9:1.

\section{Spectral data of cyclization precursors}

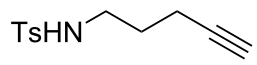

1a. In agreement with the literature data $[30,31]$.<smiles>C#CCCCCN[AsH3-]</smiles>

1b. In agreement with the literature data $[31,32]$.

\section{General procedure for the cyclization reaction}

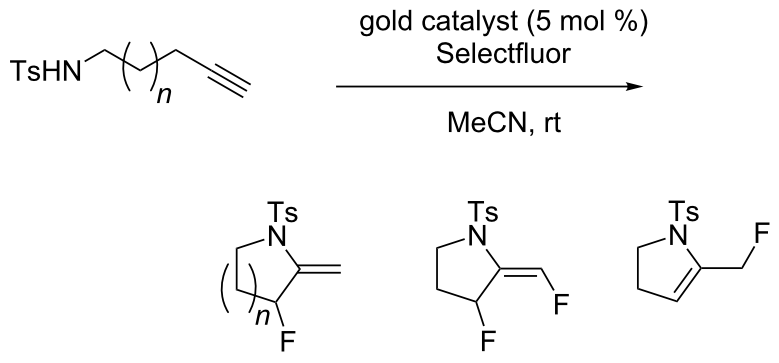

Into an oven-dried Schlenk apparatus, the Selectfluor ( $0.33 \mathrm{mmol}, 117 \mathrm{mg}, 1.1$ equiv) and the gold catalyst ( $16 \mu \mathrm{mol}$, 0.05 equiv) were loaded under a flow of argon. These solids were dried under vacuum at $70-80^{\circ} \mathrm{C}$ for $2 \mathrm{~h}$. The aminoalkyne ( $0.30 \mathrm{mmol}, 1$ equiv) was then added, followed by anhydrous MeCN (12 mL), under a flow of argon. The mixture was stirred at $\mathrm{rt}$ until complete consumption of the starting material was observed by TLC. The reaction was then filtered on a short plug of basic alumina. After removal of the solvents under reduced 
pressure, the crude product was purified by flash column chromatography on alumina with pentane/ethyl acetate $85: 15$ as eluent.

\section{Spectral data of cyclic products}

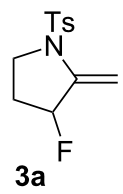

3a. White solid, mp $102{ }^{\circ} \mathrm{C} ;{ }^{1} \mathrm{H}$ NMR $\left(400 \mathrm{MHz}, \mathrm{CDCl}_{3}\right)$ $\delta 7.73(\mathrm{~d}, J=8.3 \mathrm{~Hz}, 2 \mathrm{H}), 7.30(\mathrm{~d}, J=8.1 \mathrm{~Hz}, 2 \mathrm{H}), 5.38(\mathrm{~d}, J=$ $5.2 \mathrm{~Hz}, 1 \mathrm{H}), 5.09$ (ddd, $\left.J_{\mathrm{H}-\mathrm{F}}=54.6, J_{\mathrm{H}-\mathrm{H}}=4.2,1.9 \mathrm{~Hz}, 1 \mathrm{H}\right)$, $4.76(\mathrm{~d}, J=6.0 \mathrm{~Hz}, 1 \mathrm{H}), 3.88-3.82(\mathrm{~m}, 1 \mathrm{H}), 3.63(\mathrm{td}, J=9.8$, $6.5 \mathrm{~Hz}, 1 \mathrm{H}), 2.42(\mathrm{~s}, 3 \mathrm{H}), 2.14-1.87(\mathrm{~m}, 2 \mathrm{H}) ;{ }^{19} \mathrm{~F}$ NMR $\left(376.5 \mathrm{MHz}, \mathrm{CDCl}_{3}\right) \delta-168.4(\mathrm{~m}, 1 \mathrm{~F}) ;{ }^{13} \mathrm{C} \mathrm{NMR}(101 \mathrm{MHz}$, $\left.\mathrm{CDCl}_{3}\right) \delta 144.5(\mathrm{C}), 143.2\left(\mathrm{~d}, J_{\mathrm{C}-\mathrm{F}}=15.4 \mathrm{~Hz}, \mathrm{C}\right), 134.2(\mathrm{C})$, $129.7(2 \mathrm{CH}), 127.6(2 \mathrm{CH}), 97.2\left(\mathrm{~d}, J_{\mathrm{C}-\mathrm{F}}=8.4 \mathrm{~Hz}, \mathrm{CH}_{2}\right), 93.7$ $\left(\mathrm{d}, J_{\mathrm{C}-\mathrm{F}}=178.5 \mathrm{~Hz}, \mathrm{CH}\right), 48.6\left(\mathrm{CH}_{2}\right), 29.5\left(\mathrm{~d}, J_{\mathrm{C}-\mathrm{F}}=22.3 \mathrm{~Hz}\right.$, $\left.\mathrm{CH}_{2}\right), 21.7\left(\mathrm{CH}_{3}\right)$; IR (neat) 2358, 1652, 1338, 1251, 1156, 1085, 1000, 866, 814, $651 \mathrm{~cm}^{-1}$; HRMS $(\mathrm{m} / \mathrm{z}):[\mathrm{M}+\mathrm{Na}]^{+}$calcd for $\mathrm{C}_{12} \mathrm{H}_{14} \mathrm{FNO}_{2} \mathrm{~S}, 278.0621$; found, 278.0632 .

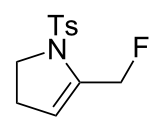

$5 a$

5a. Isolated as a minor product in mixture with $\mathbf{3 a} ;{ }^{1} \mathrm{H}$ NMR $\left(400 \mathrm{MHz}, \mathrm{CDCl}_{3}\right) \delta 7.71(\mathrm{~d}, J=8.7 \mathrm{~Hz}, 2 \mathrm{H}), 7.32(\mathrm{~d}, J=$ $8.7 \mathrm{~Hz}, 2 \mathrm{H}), 5.39-5.37(\mathrm{~m}, 1 \mathrm{H}), 5.22\left(\mathrm{~d}, J_{\mathrm{H}-\mathrm{F}}=46.8 \mathrm{~Hz}, 2 \mathrm{H}\right)$, $3.78(\mathrm{t}, J=8.9 \mathrm{~Hz}, 2 \mathrm{H}), 2.43(\mathrm{~s}, 3 \mathrm{H}), 2.33-2.22(\mathrm{~m}, 2 \mathrm{H})$; ${ }^{19} \mathrm{~F}$ NMR $\left(376 \mathrm{MHz}, \mathrm{CDCl}_{3}\right) \delta-213.6$ to $-213.9(\mathrm{~m}, 1 \mathrm{~F})$; ${ }^{13} \mathrm{C}$ NMR $\left(101 \mathrm{MHz}, \mathrm{CDCl}_{3}\right) \delta 144.1(\mathrm{C}), 139.5\left(\mathrm{~d}, J_{\mathrm{C}-\mathrm{F}}=\right.$ $20.7 \mathrm{~Hz}, \mathrm{C}), 134.1$ (C), $130.1(2 \mathrm{CH}), 127.8(2 \mathrm{CH}), 115.4$ (d, $\left.J_{\mathrm{C}-\mathrm{F}}=8.1 \mathrm{~Hz}, \mathrm{CH}\right), 78.5\left(\mathrm{~d}, J_{\mathrm{C}-\mathrm{F}}=167.4 \mathrm{~Hz}, \mathrm{CH}_{2}\right), 50.4\left(\mathrm{CH}_{2}\right)$, $27.7\left(\mathrm{CH}_{2}\right), 21.7\left(\mathrm{CH}_{3}\right)$.

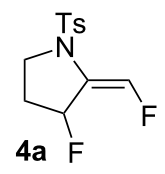

4a. White solid, mp $68{ }^{\circ} \mathrm{C} ;{ }^{1} \mathrm{H}$ NMR (400 MHz, $\left.\mathrm{CDCl}_{3}\right) \delta 7.72$ $(\mathrm{d}, J=8.3 \mathrm{~Hz}, 2 \mathrm{H}), 7.39\left(\mathrm{dd}, J_{\mathrm{H}-\mathrm{F}}=80.7, J_{\mathrm{H}-\mathrm{H}}=6.1 \mathrm{~Hz}, 1 \mathrm{H}\right)$, $7.32(\mathrm{~d}, J=8.1 \mathrm{~Hz}, 2 \mathrm{H}), 5.63\left(\mathrm{dt}, J_{\mathrm{H}-\mathrm{F}}=53.8 \mathrm{~Hz}, J_{\mathrm{H}-\mathrm{H}}=\right.$ $3.2 \mathrm{~Hz}, 1 \mathrm{H}), 3.83$ (t, $J=9.2 \mathrm{~Hz}, 1 \mathrm{H}), 3.48$ (ddd, $J=11.1,10.1$,
$6.2 \mathrm{~Hz}, 1 \mathrm{H}), 2.43(\mathrm{~s}, 3 \mathrm{H}), 2.09(\mathrm{ddd}, J=17.5,14.4,6.1 \mathrm{~Hz}$, 1H), $1.97-1.76(\mathrm{~m}, 1 \mathrm{H}) ;{ }^{19} \mathrm{~F}$ NMR $\left(376 \mathrm{MHz}, \mathrm{CDCl}_{3}\right) \delta-149.5$ $\left(\mathrm{dd}, J_{\mathrm{H}-\mathrm{F}}=80.7, J_{\mathrm{F}-\mathrm{F}}=8.9 \mathrm{~Hz}, 1 \mathrm{~F}\right),-171.6$ to $-173.7(\mathrm{~m}, 1 \mathrm{~F})$; ${ }^{13} \mathrm{C}$ NMR $\left(101 \mathrm{MHz}, \mathrm{CDCl}_{3}\right) \delta 144.8(\mathrm{C}), 142.0\left(\mathrm{dd}, J_{\mathrm{C}-\mathrm{F}}=\right.$ 250.4, 10.1 Hz, CH), 133.3 (C), 129.9 (2CH), 128.2 (C), 127.8 $(2 \mathrm{CH}), 88.1\left(\mathrm{dd}, J_{\mathrm{C}-\mathrm{F}}=178.7,3.5 \mathrm{~Hz}, \mathrm{CHF}\right), 48.7\left(\mathrm{CH}_{2}\right), 30.4$ (d, $\left.J_{\mathrm{C}-\mathrm{F}}=23.1 \mathrm{~Hz}, \mathrm{CH}_{2}\right), 21.8\left(\mathrm{CH}_{3}\right)$; IR (neat) 2359, 1597, 1353, 1163, 1133, 1090, 1060, 1011, 964, 814, $664 \mathrm{~cm}^{-1}$; HRMS $(m / z):[\mathrm{M}+\mathrm{Na}]^{+}$calcd for $\mathrm{C}_{12} \mathrm{H}_{13} \mathrm{~F}_{2} \mathrm{NO}_{2} \mathrm{~S}, 296.0527$; found, 296.0535 .<smiles>C=C1C(F)CCC[N+]1=S</smiles>

3b. Colorless oil; ${ }^{1} \mathrm{H}$ NMR (400 MHz, $\left.\mathrm{CDCl}_{3}\right) \delta 7.73(\mathrm{~d}, J=$ $8.3 \mathrm{~Hz}, 2 \mathrm{H}), 7.28(\mathrm{~d}, J=8.0 \mathrm{~Hz}, 2 \mathrm{H}), 5.35(\mathrm{~s}, 1 \mathrm{H}), 5.16(\mathrm{~s}, 1 \mathrm{H})$, $4.70\left(\mathrm{dt}, J_{\mathrm{H}-\mathrm{F}}=49.6 \mathrm{~Hz}, J_{\mathrm{H}-\mathrm{H}}=5.3 \mathrm{~Hz}, 1 \mathrm{H}\right), 3.68-3.54(\mathrm{~m}$, $2 \mathrm{H}), 2.42(\mathrm{~s}, 3 \mathrm{H}), 1.97-1.81(\mathrm{~m}, 2 \mathrm{H}), 1.73(\mathrm{~m}, 1 \mathrm{H}), 1.61-1.48$ $(\mathrm{m}, 1 \mathrm{H}) ;{ }^{19} \mathrm{~F}$ NMR $\left(376 \mathrm{MHz}, \mathrm{CDCl}_{3}\right) \delta-173.4(\mathrm{~m}, 1 \mathrm{~F})$; ${ }^{13} \mathrm{C}$ NMR $\left(101 \mathrm{MHz}, \mathrm{CDCl}_{3}\right) \delta 143.7(\mathrm{C}), 140.5\left(\mathrm{~d}, J_{\mathrm{C}-\mathrm{F}}=\right.$ $19.0 \mathrm{~Hz}, \mathrm{C}), 137.3$ (C), $129.7(2 \mathrm{CH}), 127.7$ (2CH), 110.7 (d, $\left.J_{\mathrm{C}-\mathrm{F}}=7.7 \mathrm{~Hz}, \mathrm{CH}_{2}\right), 88.4\left(\mathrm{~d}, J_{\mathrm{C}-\mathrm{F}}=178.6 \mathrm{~Hz}, \mathrm{CHF}\right), 46.9$ $\left(\mathrm{CH}_{2}\right), 30.7\left(\mathrm{~d}, J_{\mathrm{C}-\mathrm{F}}=21.7 \mathrm{~Hz}, \mathrm{CH}_{2}\right), 21.7\left(\mathrm{CH}_{3}\right), 20.9\left(\mathrm{~d}, J_{\mathrm{C}-\mathrm{F}}\right.$ $=5.4 \mathrm{~Hz}, \mathrm{CH}_{2}$ ); IR (neat) 1647, 1598, 1451, 1340, 1157, 1098, 1057, 950, 908, 814, 690, $653 \mathrm{~cm}^{-1}$; HRMS $(\mathrm{m} / z):[\mathrm{M}+\mathrm{Na}]^{+}$ calcd for $\mathrm{C}_{13} \mathrm{H}_{16} \mathrm{FNO}_{2} \mathrm{~S}, 292.0778$; found, 292.0776.

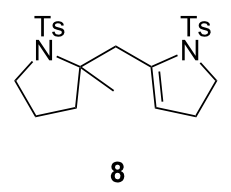

8. White solid, mp $66{ }^{\circ} \mathrm{C}$; ${ }^{1} \mathrm{H}$ NMR $\left(300 \mathrm{MHz}, \mathrm{CDCl}_{3}\right) \delta 7.74$ $(\mathrm{d}, J=8.2 \mathrm{~Hz}, 2 \mathrm{H}), 7.65(\mathrm{~d}, J=8.1 \mathrm{~Hz}, 2 \mathrm{H}), 7.30$ (d, $J=$ $5.2 \mathrm{~Hz}, 2 \mathrm{H}), 7.28$ (d, $J=6.3 \mathrm{~Hz}, 2 \mathrm{H}), 5.41$ (br s, 1H), 3.89-3.69 (m, 2H), 3.54-3.46 (m, 1H), 3.30-3.23 (m, 3H), 2.66-2.52 (m, $1 \mathrm{H}), 2.44(\mathrm{~s}, 3 \mathrm{H}), 2.42(\mathrm{~s}, 3 \mathrm{H}), 2.01-1.87(\mathrm{~m}, 3 \mathrm{H}), 1.78-1.58$ (m, 2H), $1.41(\mathrm{~s}, 3 \mathrm{H}) ;{ }^{13} \mathrm{C}$ NMR $\left(75 \mathrm{MHz}, \mathrm{CDCl}_{3}\right) \delta 143.9(\mathrm{C})$, $142.8(\mathrm{C}), 140.9(\mathrm{C}), 138.8(\mathrm{C}), 134.1(\mathrm{C}), 129.7(2 \mathrm{CH}), 129.5$ $(2 \mathrm{CH}), 127.8(2 \mathrm{CH}), 127.3(2 \mathrm{CH}), 119.5(\mathrm{CH}), 68.20(\mathrm{C}), 51.3$ $\left(\mathrm{CH}_{2}\right), 49.9\left(\mathrm{CH}_{2}\right), 39.6\left(\mathrm{CH}_{2}\right), 39.2\left(\mathrm{CH}_{2}\right), 27.7\left(\mathrm{CH}_{2}\right), 26.6$ $\left(\mathrm{CH}_{3}\right), 22.7\left(\mathrm{CH}_{2}\right), 21.7\left(\mathrm{CH}_{3}\right), 21.6\left(\mathrm{CH}_{3}\right)$; IR (neat) 1452, 1332, 1154, 1089, 1000, 811, $655 \mathrm{~cm}^{-1}$; HRMS $(\mathrm{m} / \mathrm{z})$ : $[\mathrm{M}+\mathrm{Na}]^{+}$calcd for $\mathrm{C}_{24} \mathrm{H}_{30} \mathrm{~N}_{2} \mathrm{O}_{4} \mathrm{~S}_{2}, 497.1539$; found, 497.1517 . 


\section{Synthesis of cyclic enamines}

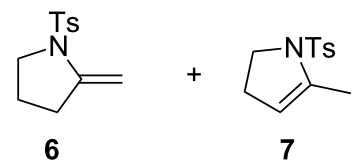

Cyclic enamines were synthesized in 59\% yield (endo/exo 2:3) according to a literature procedure [32]. Spectral data matched those reported.

\section{General procedure for the fluorination reactions of the enamines}<smiles>C=C1CCCN1[AsH3-]</smiles>

6
Cond. A

Selectfluor (1 equiv) $\mathrm{MeCN}, \mathrm{rt}$

Cond. B

$\mathrm{Ph}_{3} \mathrm{PAuCl}(5 \mathrm{~mol} \%)$

Selectfluor (1.1 equiv) $\mathrm{MeCN}, \mathrm{rt}$

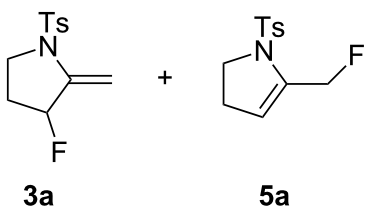

Conditions A: In an oven-dried Schlenk apparatus the Selectfluor $(0.17 \mathrm{mmol}, 1$ equiv) was loaded under a flow of argon. This was then dried under vacuum at $70-80{ }^{\circ} \mathrm{C}$ for $2 \mathrm{~h}$. The mixture of cyclic enamines $(0.17 \mathrm{mmol}, 40 \mathrm{mg}, 1$ equiv) was then added, followed by anhydrous $\mathrm{MeCN}(7 \mathrm{~mL})$, under a flow of argon. The mixture was stirred at rt until complete consumption of the starting material was observed by TLC. The reaction mixture was then filtered on a short plug of basic alumina. After removal of the solvents under reduced pressure, the crude product was purified by flash column chromatography on alumina with pentane/ethyl acetate $85: 15$ as eluent.

Conditions B: In an oven-dried Schlenk apparatus, the Selectfluor ( $0.33 \mathrm{mmol}, 117 \mathrm{mg}, 1.1$ equiv) and triphenylphosphine gold chloride ( $16 \mu \mathrm{mol}, 7.4 \mathrm{mg}, 0.05$ equiv) were loaded under a flow of argon. These solids were dried under vacuum at $70-80{ }^{\circ} \mathrm{C}$ for $2 \mathrm{~h}$. A mixture of cyclic enamines $(0.3 \mathrm{mmol}$, $72 \mathrm{mg}, 1$ equiv) was then added, followed by anhydrous $\mathrm{MeCN}$ $(12 \mathrm{~mL})$, under a flow of argon. The mixture was stirred at $\mathrm{rt}$ until complete consumption of the starting material was observed by TLC. The reaction was then filtered on a short plug of basic alumina. After removal of the solvents under reduced pressure, the crude product was purified by flash column chromatography on alumina with pentane/ethyl acetate $85: 15$ as eluent.

\section{Supporting Information}

\section{Supporting Information File 1}

${ }^{1} \mathrm{H},{ }^{13} \mathrm{C},{ }^{19} \mathrm{~F}$ NMR spectra of products $\mathbf{3 a}, \mathbf{4 a}, \mathbf{5 a}, \mathbf{3 b}$ and $\mathbf{8}$.

[http://www.beilstein-journals.org/bjoc/content/

supplementary/1860-5397-7-162-S1.pdf]

\section{Acknowledgements}

We thank UPMC, Ministère de la Recherche et de l'Enseignement Supérieur, CNRS, IUF (M. M., L. F.). Technical assistance was generously offered by FR 2769 and we are grateful to Elsa Caytan for the ${ }^{19} \mathrm{~F}$ NMR experiments.

\section{References}

1. Kirsch, P. Modern Fluoroorganic Chemistry; Wiley-VCH: Weinheim, Germany, 2004.

2. Ojima, I. Fluorine in Medicinal Chemistry and Chemical Biology; Wiley-Blackwell: Chichester, 2009. doi:10.1002/9781444312096

3. De Haro, T.; Nevado, C. Adv. Synth. Catal. 2010, 352, 2767-2772. doi:10.1002/adsc.201000559

4. Akana, J. A.; Bhattacharyya, K. X.; Müller, P.; Sadighi, J. P. J. Am. Chem. Soc. 2007, 129, 7736-7737. doi:10.1021/ja0723784

5. Schuler, M.; Silva, F.; Bobbio, C.; Tessier, A.; Gouverneur, V. Angew. Chem., Int. Ed. 2008, 47, 7927-7930. doi:10.1002/anie.200802162

6. de Haro, T.; Nevado, C. Chem. Commun. 2011, 47, 248-249. doi:10.1039/C002679D

7. Moreau, X.; Goddard, J.-P.; Bernard, M.; Lemière, G.; López-Romero, J. M.; Mainetti, E.; Marion, N.; Mouriès, V.; Thorimbert, S.; Fensterbank, L.; Malacria, M. Adv. Synth. Catal. 2008, 350, 43-48. doi:10.1002/adsc.200700356

8. Marion, N.; Lemière, G.; Correa, A.; Costabile, C.; Ramón, R. S.; Moreau, X.; de Frémont, P.; Dahmane, R.; Hours, A.; Lesage, D.; Tabet, J.-C.; Goddard, J.-P.; Gandon, V.; Cavallo, L.; Fensterbank, L.; Malacria, M.; Nolan, S. P. Chem.-Eur. J. 2009, 15, 3243-3260. doi:10.1002/chem.200801387

9. Harrak, Y.; Makhlouf, M.; Azzaro, S.; Mainetti, E.; Lopez Romero, J. M.; Cariou, K.; Gandon, V.; Goddard, J.-P.; Malacria, M.; Fensterbank, L. J. Organomet. Chem. 2011, 696, 388-399. doi:10.1016/j.jorganchem.2010.10.016

10. Harrak, Y.; Simmonneau, A.; Malacria, M.; Gandon, V.; Fensterbank, L. Chem. Commun. 2010, 46, 865-867. doi:10.1039/B919240A

11. Benedetti, E.; Lemière, G.; Chapellet, L.-L.; Penoni, A.; Palmisano, G.; Malacria, M.; Goddard, J.-P.; Fensterbank, L. Org. Lett. 2010, 12, 4396-4399. doi:10.1021/ol101889h

12. Wang, W.; Jasinski, J.; Hammond, G. B.; Xu, B. Angew. Chem., Int. Ed. 2010, 49, 7247-7252. doi:10.1002/anie.201003593

13. Qian, J.; Liu, Y.; Zhu, J.; Jiang, B.; Xu, Z. Org. Lett. 2011, 13, 4220-4223. doi:10.1021/ol201555z

14. Xu, T.; Mu, X.; Peng, H.; Liu, G. Angew. Chem., Int. Ed. 2011, 50, 8176-8179. doi:10.1002/anie.201103225

15. Hashmi, A. S. K.; Ramamurthi, T. D.; Rominger, F. J. Organomet. Chem. 2009, 694, 592-597. doi:10.1016/j.jorganchem.2008.11.054 
16. Engle, K. M.; Mei, T.-S.; Wang, X.; Yu, J.-Q. Angew. Chem., Int. Ed. 2011, 50, 1478-1491. doi:10.1002/anie.201005142

17. Hopkinson, M. N.; Gee, A. D.; Gouverneur, V. Chem.-Eur. J. 2011, 17, 8248-8262. doi:10.1002/chem.201100736

18. Ney, J. E.; Wolfe, J. P. Angew. Chem., Int. Ed. 2004, 43, 3605-3608. doi:10.1002/anie.200460060

19. Hong, S.; Marks, T. J. Acc. Chem. Res. 2004, 37, 673-686. doi:10.1021/ar040051r

20. Brenzovich, W. E.; Benitez, D.; Lackner, A. D.; Shunatona, H. P.; Tkatchouk, E.; Goddard, W. A., III; Toste, F. D. Angew. Chem., Int. Ed. 2010, 49, 5519-5522. doi:10.1002/anie.201002739

21. Hannedouche, J.; Collin, J.; Trifonov, A.; Schulz, E. J. Organomet. Chem. 2011, 696, 255-262. doi:10.1016/j.jorganchem.2010.09.013

22. Trost, B. M.; Maulide, N.; Livingston, R. C. J. Am. Chem. Soc. 2008, 130, 16502-16503. doi:10.1021/ja807696e

23. Rudolph, M.; Hashmi, A. S. K. Chem. Commun. 2011, 47, 6536-6544. doi:10.1039/C1CC10780A

24. Hirano, K.; Inaba, Y.; Takahashi, N.; Shimano, M.; Oishi, S.; Fujii, N.; Ohno, H. J. Org. Chem. 2011, 76, 1212-1227. doi:10.1021/jo102507c

25. Peng, H.; Liu, G. Org. Lett. 2011, 13, 772-775. doi:10.1021/ol103039x

26. Yeom, H.-S.; So, E.; Shin, S. Chem.-Eur. J. 2011, 17, 1764-1767. doi:10.1002/chem.201002863

27. Mankad, N. P.; Toste, F. D. J. Am. Chem. Soc. 2010, 132, 12859-12861. doi:10.1021/ja106257n

28. ${ }^{19} \mathrm{~F}$ NMR monitoring of the reaction of an equimolar mixture of Selectfluor and $\mathrm{PPh}_{3} \mathrm{AuCl}$ in $\mathrm{CD}_{3} \mathrm{CN}$ indicated that it is a rather slow process. After $3 \mathrm{~h}$ at rt, a 5:1 Selectrfluor/A ratio was obtained; after 5 $\mathrm{h}$, this ratio became $4: 1$ and after $24 \mathrm{~h}$, gold nanoparticles were observed and signals of $\mathbf{A}$ vanished. This precluded the isolation of species $\mathbf{A}$ and its further use as a reagent.

29. Peng, W.; Shreeve, J. M. J. Org. Chem. 2005, 70, 5760-5763. doi:10.1021/jo0506837

30. Schomaker, J. M.; Geiser, A. R.; Huang, R.; Borhan, B. J. Am. Chem. Soc. 2007, 129, 3794-3795. doi:10.1021/ja068077w

31. Garcia, P.; Evanno, Y.; George, P.; Sevrin, M.; Ricci, G.; Malacria, M.; Aubert, C.; Gandon, V. Org. Lett. 2011, 13, 2030-2033. doi:10.1021/ol200417p

32. Fix, S. R.; Brice, J. L.; Stahl, S. S. Angew. Chem., Int. Ed. 2002, 41, 164-166. doi:10.1002/1521-3773(20020104)41:1<164::AID-ANIE164>3.0.CO;2B

\section{License and Terms}

This is an Open Access article under the terms of the Creative Commons Attribution License

(http://creativecommons.org/licenses/by/2.0), which permits unrestricted use, distribution, and reproduction in any medium, provided the original work is properly cited.

The license is subject to the Beilstein Journal of Organic Chemistry terms and conditions:

(http://www.beilstein-journals.org/bjoc)

The definitive version of this article is the electronic one which can be found at:

doi:10.3762/bjoc.7.162 